\title{
Dois ecos longínquos de tambores na noite
}

\author{
Walder Gervásio Virgulino de Souza
}

\section{SciELO Books / SciELO Livros / SciELO Libros}

SOUZA, W.G.V. Dois ecos longínquos de tambores na noite. In: FLORENTINO, A., and TELLES, N., eds. Cartografias do ensino do teatro [online]. Uberlândia: EDUFU, 2008, pp. 309-322. ISBN 978-85-7078-518-3. https://doi.org/10.7476/9788570785183.0030.

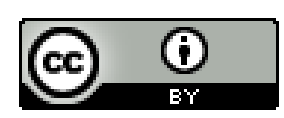

All the contents of this work, except where otherwise noted, is licensed under a Creative Commons Attribution 4.0 International license.

Todo o conteúdo deste trabalho, exceto quando houver ressalva, é publicado sob a licença Creative Commons Atribição $\underline{4.0}$.

Todo el contenido de esta obra, excepto donde se indique lo contrario, está bajo licencia de la licencia $\underline{\text { Creative Commons }}$ Reconocimento 4.0. 


\section{DOIS ECOS LONGÍNQUOS DE TAMBORES NA NOITE}

ou

exercícios livres (ou seja, tratados com humor) em torno das ações e lições de dois dramas modernos pedagógicos, escritos por alemães da ex-RDA antes da queda do muro de Berlim

Walder Gervásio Virgulino de Souza

\section{Uma parábola-diálogo com a infância do teatro}

Um dia, numa Alemanha dividida, conheci um espectador que era cego. Apreciava o teatro de rua, mas não suportava o teatro que se fazia em espaços fechados. Porque amava o fato de poder deslocar seu olhar, em liberdade, de um lado para outro, pelas praças em que os espetáculos de rua aconteciam; porque amava deslocar-se guiado por sua mulher, espectadora como ele, atraídos os dois pelas canções que os atores cantavam, por suas vozes múltiplas que surgiam ora daqui, ora dali, vindas do alto ou de baixo, da direita ou da esquerda.

Meu amigo cego (tornamo-nos amigos) revelou-me, então, que as imagens cênicas se formavam diante dele, em torno dele - ele as "via"! - e se sentia, ao mesmo tempo, participando não somente com os outros espectadores, mas também com os atores de um único jogo teatral, do espetáculo de rua. Era um jogo coletivo, contou-me, emocionante demais, ao qual se sentia completamente integrado.

\section{O jogo teatral do ponto de vista do espectador ou olhares sobre aqueles que olham}

- [...] Eu sempre vou amaldiçoá-lo [o teatro] por perturbar a paz de minha casa por tua paixão imoderada por este prazer. [...] disse a mãe.

-Mas que diferença quando estamos sentados diante dela (a cortina do teatro)! Mesmo se tivermos que esperar muito tempo, sabemos que ela se levantará e veremos as coisas mais variadas que nos distraem, nos instruem e nos elevam ${ }^{1}$.

Gostaria sempre de falar (enquanto ator e professor) ou de escrever textos

1 GOETHE. Les années d'apprentissage de Wilhelm Meister. Traduit de l'allemand par Jeanne Ancelet-Hustache. Paris: Aubier-Montaigne, 1983. p. 44. 
teóricos que pudessem fazer mexer meus espectadores, alunos ou leitores, o que não quer dizer, necessariamente, que desejo fazer com que pulem para a cena, incitando-os a se levantarem de suas cadeiras e agirem. Mas, simplesmente, fazer-lhes (fazer-me) refletir um pouco mais sobre nossa condição de indivíduos e dar-nos consciência do papel ativo que representamos em qualquer tipo de fazer teatral.

Uma situação particular de minha vida profissional, no entanto, leva-me, neste texto, a iniciar minha viagem a partir da lembrança do instante em que retomo, a cada semestre, minhas atividades de professor do Departamento de Teoria da Escola de Teatro da Uni-Rio e tenho de escolher os textos teatrais que trabalharemos juntos, eu, na posição de professor-ator-teórico, e eles, quase meia centena de rapazes e moças, de idades as mais variadas, todos ingressantes na Universidade, como alunos-atores, teóricos, diretores, cenógrafos ou licenciandos em teatro. Desenvolverei aqui exercícios em torno de dois textos alemães exemplares, que tratarei como modelos do trabalho mais amplo de conscientização profissional que realizamos em atividades coletivas, numa sala de aula vista sempre como espaço dramático, e em que nos revezaremos, professor ou alunos, ora como atores, ora como espectadores de um jogo teatral específico, que exigirá, de cada um de nós, uma preparação em total liberdade e uma legítima atitude lúdica.

Poderia, certamente, centrar minha reflexão, desde o início, sobre a maneira como atores e espectadores participam juntos do jogo teatral, mas preferi privilegiar, como objeto de minhas primeiras observações, apenas a conduta e as reações isoladas dos que observam o jogo desempenhado pelo ator. Em dois livros que teorizam sobre o assunto: Les jeux et les hommes (Os jogos e os bomens), de Roger Caillois, e Le jeu (O Jogo), de Jacques Henriot, esses autores se interessaram pela definição e classificação das coisas denominadas "jogos” ou pela atividade de "jogar", considerando-os principalmente do ponto de vista do jogador (ou do ator, no que se refere aos jogos de simulacro) e esqueciam ou só atribuíam uma função secundária ao jogo do espectador, que é, por sua vez, ele também um “jogador”.

Para Caillois, o sistema dos jogos apresenta quatro tipos diversos, na medida em que neles predomine a função de competição, de acaso, de simulacro ou de vertigem. No jogo teatral, segundo o autor, predomina o simulacro. Para designá-lo, escolheu a expressão inglesa mimicry, que corresponde a "mimetismo":

Encontramo-nos, então, diante de uma série variada de manifestações que têm por caráter comum apoiar-se no fato de que o sujeito acredita ser ou faz os outros acreditarem que ele é um outro que não ele [...] e [nestas manifestações] ele inventa um mundo fictícioº .

[Tais jogos de simulacro] aparecem na criança sob a forma do jogo simbólico e, no adulto, em todas as condutas psico-sociais que são a máscara, o papel que representa socialmente, o personagem ${ }^{3}$.

\footnotetext{
CAILLOIS, Roger. Les jeux et les hommes. Paris: Gallimard, 1967. p. 61, 103.
}

${ }^{3}$ HENRIOT, Jacques. Le jeu. Paris: Synonyme, 1983. p. 46. 
De saída, uma distinção se impõe. Apesar de o ator e a criança proporem uma conduta associada a imagens, o ator, ao contrário da criança, sabe que ele representa para os outros. E assim, de imediato, surgem elementos que são regras, limites, convenções do jogo, embora atuados com relativa liberdade. Em princípio, sente-se obrigado a apresentar condutas identificáveis, na medida em que pretende comunicar-se com os outros. A partir daí, outros elementos vêm compor esta compreensão do que seja um jogo teatral. Atualmente, este tipo específico de encontro de seres humanos está dividido em dois subgrupos: espectadores e atores, que juntos vão participar de uma atividade prática de ruptura com a realidade quotidiana, em que imagens de representação mental são construídas e começam a circular da maneira mais econômica possível entre eles. Trata-se de um imaginário comum simbólico que, num dado grupo social, pode tomar toda espécie de formas e de significações sucessivas. $\mathrm{O}$ jogo teatral vai se dar, exatamente, no ponto de tensão entre a comunicação totalmente codificada e a mais livre invenção. O que um espectador percebe do jogo do ator e vice-versa? Quais são os signos que percebem e o que constroem a partir do que percebem?

\section{A atitude lúdica: uma visão de jogo como êxtase dinâmico do homem}

[...] Cada homem traz em si a sua dose de ópio natural, incessantemente segregada e renovada; e do nascimento à morte, quantas horas podemos contar cheias pelo verdadeiro prazer, pela ação feliz e resoluta? Viveremos jamais, conheceremos algum dia esse quadro que o meu espírito pintou, esse quadro que se parece contigo? $[\ldots]^{4}$.

Mais uma vez deve ser lembrado que essa missão [do ator] é a de recrear os filhos de uma era científica [os espectadores] proporcionando-lhes o prazer dos sentidos e a alegria. [...] Do prazer sexual, extraímos deveres conjugais; o prazer artístico está ao serviço da cultura, e aprender não significa conhecer aprazivelmente, mas, sim, aferrar o nariz ao objeto do conhecimento. Nada do que fazemos representa um esforço aprazível, e, para justificarmos os nossos atos, não invocamos o que gozamos com isto ou com aquilo, mas, sim, quanto suor nos custou ${ }^{5}$.

Torna-se necessário que os atores e espectadores tenham consciência do fato de estarem juntos e jogarem juntos ao longo do "espetáculo" teatral. Na verdade, só há troca teatral quando estes dois sujeitos, o ator e o espectador, podem compreender e aceitar a dimensão de seu próprio jogo e do jogo do outro. O ator é, evidentemente, o primeiro a agir, cabendo-lhe a iniciativa de jogar, mas o jogo teatral só se completará após a inclusão das reações do público.

No entanto, em nossos espaços de jogo, estarão sempre incrustradas e pressupostas, nos gestos e atitudes do ator ou do espectador, as chances de desenvolverem aspectos secretos e misteriosos de todos os participantes, que poderão e deverão utilizar sutilezas de suas livres associações, provenientes do foro particular e do mais

${ }^{4}$ BAUDELAIRE, Charles. O convite à viagem. In: Pequenos poemas em prosa. Tradução de Aurélio Buarque de Hollanda. Rio de Janeiro: J. Olympio, 1950. p. 58-59. (Coleção Rubáiyat).

${ }^{5}$ BRECHT, Bertolt. Pequeno organon para o teatro (fragmento 75). In: teatro. Tradução de Fiama Pais Brandão. Rio de Janeiro: Nova Fronteira, $\overline{978 . ~ p .} 133$. 
íntimo de cada um. A entrada no jogo é, portanto, este momento em que o ator ou o espectador ficcionalizam o mundo real, isto é, aquele momento em que vivem atos que aparentemente não pertencem ao real quotidiano, mas a um mundo fictício, separado. Para analisarmos o teatro enquanto jogo, devemos nos colocar sempre nesta espécie de entre-dois, nesta evidente zona de fronteira, de um real que pode ser visto como ficção, que pode ser vivido como falso, mas que se admite, mesmo assim, como um pseudo-real (ou um verdadeiro real).

Uma outra característica da atitude lúdica é a incerteza. Segundo J. Henriot, aquela margem de indeterminação, que tornaria o comportamento dos jogadores totalmente imprevisível. Na minha opinião, o fundamento mesmo do ato teatral enquanto expressão coletiva de um grupo de pessoas, de uma turma de alunos de uma dada sociedade.

Expliquemos. Quando um aluno ou um ator entra em cena, nos exercícios de cada aula ou de cada ensaio, propõe ao espectador o resultado parcial de um trabalho paciente de preparação de sua leitura de uma obra. Como se trata de um artista em ensaio, vivendo uma situação experimental, o público presume que este ator, ao qual teria delegado seu poder de representar, está aprendendo a dominar técnicas de sua arte e que ele lhe mostrará, com seu corpo e movimentos, imagens cujos pormenores estarão sendo objeto de sua pesquisa em cena.

Trata-se, assim, de uma aventura coletiva vivenciada por atores e espectadores, durante a qual se constituirão imagens comuns. Uma aventura que deve ser qualificada, segundo o fenomenologista Jankélévitch, como "aventurosa”, o que não tem nada a ver com uma mera aventura "aventureira". Os atores e espectadores aventurosos representam "[...] um verdadeiro estilo de vida, enquanto que os aventureiros não passariam de meros profissionais das aventuras. [...] As baixas e inferiores aventuras aventureiras não passariam de caricaturas das aventuras aventurosas"6.

Esta aventura implicaria, na verdade, numa oscilação da consciência entre o jogo e o sério. Continua o fenomenologista:

Suprimam um dos contrários - o jogo ou o sério - e a aventura deixa de ser aventurosa. Optando pela supressão do elemento lúdico, a aventura torna-se tragédia; suprimindo o sério, a aventura vira jogo de cartas, passatempo derrisório, aventura fingidora ${ }^{7}$.

\section{Da pseudopassividade do espectador à ocupação dos espaços Anda, Luzia, pega o pandeiro e vem pro Carnaval... Anda, Luzia, que esta tristeza lhe vai muito mal.}

O trabalho de fato começa quando digo aos alunos que o semestre em que nos conhecemos será marcado por uma enorme aventura aventurosa pelo mundo das possibilidades do teatro contemporâneo. Proponho que a escolha dos textos seja feita, então, de acordo com a necessidade de cada turma e com a possibilidade de cada um de nós descobrir e experimentar, em nossas vidas e em nossos corpos, que o teatro pode não

\footnotetext{
6 JANKÉLÉVITCH, Vladimir. L'aventure, l'ennui, le sérieux. Paris: Aubier-Montaigne, 1963. p. 10.

7 JANKELÉVITCH, 1963, p. 13.
} 
ser nada do que conhecemos até agora; que houve muitos experimentadores de formas novas, que abalaram e propuseram saídas, ao longo do século XX, tanto no mundo da dramaturgia tradicional como no mundo da pesquisa de soluções (e revoluções) da própria cena. Falo muito das novas formas de representação e não só das teorias da representação de Aristóteles ou das formas de um teatro psicológico, que Antonin Artaud enxergava como partindo das tragédias de influência jansenista de Jean Racine. Mostro o mundo das peças didáticas de Bertolt Brecht, da explosão crítica de seu teatro nas mãos e na sensibilidade de Heiner Müller. Encorajo-os para que leiam muito sobre as experiências de Artaud e de sua busca consciente de um corpo sem órgãos, de como suas teorias foram retomadas e sistematizadas, na segunda metade do século XX, por homens de teatro como Jerzy Grotowski, Bob Wilson, Peter Brook. Incentivo meus alunos para que entrem em contato com as obras críticas contemporâneas de brasileiros e estrangeiros e que comprem muitos livros (não só peças) e discutam todas as formas do fazer teatral. Que leiam, se possível, como me recomendou um dia o diretor Amir Haddad, uma peça (ou um texto teórico) por dia. Que questionem bastante o que lhes ensinamos em nossa Universidade, que sejam capazes de dialogar com nossas diferenças e tomem, por favor, sempre por base o lema da leitura infinita, que considero a arma mais eficaz para determinar a escolha do teatro que querem fazer. Divido a turma (refiro-me, ao longo deste texto, sempre aos 50 alunos que ingressam na Uni-Rio por semestre) em grupos menores com sete ou oito integrantes e digo-lhes: "Cada grupo deve buscar sua leitura particular, saindo de sua pseudo-passividade de espectador, experimentando com base no que vêm aprendendo nos palcos do 'mundo', nas salas de aula, em que talvez sejam também professores e, principalmente, a partir da bela ou triste história de vida múltipla de cada um”. Imaginei esta longa introdução como um exemplo da necessidade de que haja, além das experiências de cada grupo, uma proposta de leitura e experimentação, ao longo do semestre, das peças oferecidas como temas e formas de discussão teatrais possíveis. Na presente análise, ilustrando a questão "O texto dramático na sala de aula”, forneço algum material para reflexão a partir de minha leitura pessoal - integrado às descobertas de cada grupo isolado - destes dois autores alemães fundamentais. Ao longo de minha vida, descobri as linhas centrais de meu interesse de estudo, as oferecidas pela cena alemã e as imaginadas pelo teatro brasileiro a partir da dramaturgia de Nelson Rodrigues, bem como pelo teatro desenvolvido na França em todos os tempos.

\section{O diálogo possível entre Mauser, de Heiner Müller, e $A$ Decisão (Die Massnabme), de Bertolt Brecht, duas peças didáticas do século XX}

Nosso exercício tentará estar atento ao diálogo imaginário entre os textos de duas peças didáticas do teatro alemão moderno.

A Decisão, de Brecht, é nosso ponto de partida. Escrita entre 1929 e 1930, após o suicídio de Maïakovski, esta peça teve o mérito de descrever o problema fundamental do socialismo "de que sejam sempre os melhores, em suas próprias fileiras - a elite intelectual, portanto - que tenham de ser eliminados" ". A Decisão tem a força destes grandes textos, destes tambores eloqüentes que, começando a ressoar já no final dos anos vinte do

${ }^{8}$ GOTSCHEFF, Dimiter. Nous maintiendrons le virus en vie. In: confessions, mémoires, analyses. Paris: L'Arche, 1993. p. 28.

. Brectht après la chute: 
século XX, vão tornar-se documentos essenciais à compreensão dos anos hitleristas que virão a seguir e dos julgamentos sumários que ocorrerão ao longo dos anos stalinistas de construção da República Democrática da Alemanha - RDA, esta então nova República socialista européia.

Mauser é um eco longínquo deste tambor brechtiano que bate na noite, ou seja, da teoria e da prática de suas peças didáticas. Escrita em 1970 por Heiner Müller, ela é a terceira de uma série experimental, "sendo a primeira Philoktet (Filocteto) e a segunda Der Horatier (O Horaciano)" " e pode, talvez, ser considerada como uma variação em torno de aspectos formais e temáticos de $A$ Decisão. Existe, na Alemanha, esta tendência a se trabalhar, de forma experimental, temas tratados anteriormente por outros escritores, a retomar criticamente o que chamam de "antigas situações-modelo". Aliás, é o próprio Müller que nos adverte, a propósito de Mauser, que não se trata de uma "peça de repertório", mas de uma peça experimental. "Escrevi uma peça que, pelo assunto, é uma variação de $A$ Decisão, ou uma continuação. [...] Prossigo com esta peça a partir do momento em que $A$ Decisão foi interrompida"10. O conteúdo das duas peças.

BRECHT - "A Decisão mostra um tribunal do Partido Comunista. A comissão de controle, encarnada pelo Coro, deve julgar quatro agitadores que trabalham na clandestinidade. No interesse da causa, foram obrigados a suprimir um quinto companheiro, um jovem militante que, sensível e indisciplinado demais, ameaçava o partido com uma catástrofe" ${ }^{\prime 1}$.

O CORO DE CONTROLE - (...) também nesse país a revolução está em marcha, e as fileiras estão organizadas. Estamos de acordo com vocês.

OS QUATRO AGITADORES - (...) Queremos comunicar a morte de um camarada.

O CORO DE CONTROLE - Quem o matou?

OS QUATRO AGITADORES - Nós o matamos. Atiramos nele e o jogamos numa mina de cal.

O CORO DE CONTROLE - O que ele fez para que vocês o matassem?

OS QUATRO AGITADORES - Muitas vezes fez o que era certo, algumas vezes o que era errado, mas por último colocou em risco o movimento. Ele queria o certo e fez o errado. Exigimos sua sentença.

O CORO DE CONTROLE - Mostrem-nos como e por que aconteceu e ouvirão nossa sentença ${ }^{12}$.

(Uma passagem do julgamento de Brecht pela Comissão de Defesa do governo dos Estados Unidos).

\footnotetext{
9 MÜLLER, Heiner. Quatro textos para teatro: Mauser, Hamlet-máquina, a missão, quarteto. Apresentação de Fernando Peixoto. São Paulo: Editora Hucitec: Associação Cultural Bertolt Brecht, 1987. p. 21.

10 Apud MAIER-SCHAFFER, F. Heiner Müller et la Lebrstück. Berne: P. Lang, 1992. p. 86.

11 Apud BETZ, Albrecht et al. L'état d'urgence chez Carl Schmitt et La décision chez Bertolt Brecht. In: STORCH, Wolfgang (Dir.). Brecht après la chute. Confessions, mémoires, analyses. Paris: L'Arche, 1993. p. 36-37.

12 BRECHT, Bertolt. A decisão (1929-1930). In:

Dormien Koudela. Rio de Janeiro: Paz e Terra, 1988. v. 3, p. 237.
} 
BRECHT - Esta peça [A Decisão] é uma adaptação de uma antiga peça religiosa japonesa, e é uma "peça didática". Segue fielmente a narrativa original e mostra alguém que se sacrifica por um ideal, chegando ao ponto de morrer por ele.

STRIPLING - Então, senhor Brecht, poderia confirmar à Comissão se é exato que um dos personagens de A Decisão foi assassinado por seus camaradas pelo bem do Partido, do Partido Comunista...

BRECHT - De forma alguma. (...) Este rapaz, ao morrer, estava persuadido de ter colocado em risco a causa em que acreditava, e aceitava morrer para não prejudicar ainda mais o movimento. Por este motivo, pede a seus camaradas que o ajudem a morrer. Ele se atira num precipício, depois de ter sido levado até lá. É esta a história ${ }^{13}$.

O JOVEM CAMARADA - Meu coração bate pela Revolução. Ela está aqui (...). Mas agora seria melhor se eu não existisse. (...) No interesse do comunismo/ De acordo com o avanço das massas proletárias/ De todos os países,/ Afirmando a revolução mundial. $(\ldots)^{14}$.

\section{CANÇÃO DA MERCADORIA}

(...) O que é um homem, afinal?

Eu lá sei o que é um homem?

(...) Não sei o que é um homem.

Eu só conheço o seu preço.

MAS QUEM É O PARTIDO? (...)

OS 3 AGITADORES - O Partido somos nós.

Você e eu e vocês - nós todos. (...).

O CORO DE CONTROLE

ELOGIO AO PARTIDO

$\mathrm{O}$ indivíduo tem dois olhos.

O Partido tem milhares de olhos. (...).

O CORO DE CONTROLE - Não foram vocês que pronunciaram a sua sentença, mas sim a realidade. (...).

OS QUATRO AGITADORES - Então perguntamos: você está de acordo?

Pausa.

O JOVEM CAMARADA - Sim. Vejo que sempre agi erradamente. (...).

O CORO DE CONTROLE - Compreensão da parte e compreensão do todo:

Só ensinados pela realidade é que podemos

Transformar a realidade ${ }^{15}$.

HEINER MÜLLER - “Mauser, por sua vez, expõe também um "processo judicial”

${ }_{13}$ BRECHT, 1988, p. 45-49.

${ }^{14}$ BRECHT, 1988, p. 260-265.

15 BRECHT, 1988, p. $254-266$. 
em que "A", um revolucionário experiente, ao contrário do Jovem Camarada, um jovem militante, é acusado diante de um tribunal, no qual deve se dizer de acordo com sua própria condenação à morte. A última cena de Mauser, a execução de "A", corresponderia ao ponto de partida da peça de Brecht" ${ }^{16}$.

CORO - (...) Você aplicou a morte na cidade de Witebski

Aos inimigos da revolução, por nosso encargo

Sabendo que o pão de cada dia da revolução

$\mathrm{Na}$ cidade de Witebski como em outras cidades

É a morte de seus inimigos, sabendo que ainda

Precisamos arrancar a relva para que o verde permaneça (...)

A - Cumpri a minha missão.

CORO - Cumpra agora a sua derradeira

A - Eu matei pela revolução.

CORO - Morra agora por ela.

A - Cometi um erro.

CORO - Você é o erro.

A - Sou um ser humano.

CORO - O que é isso?

A - Não quero morrer.

CORO - $\quad$ (...) A revolução não precisa mais de você. Ela precisa da sua morte. Mas antes de dizer SIM ao NÃO que foi sentenciado contra você,

Não terminou a sua tarefa ${ }^{17}$.

$\mathrm{O}$ "Coro" e "A" se tratam por "você" e ficam assim mais à vontade para explicar os motivos de suas ações e decisões. Estão todos num plano de igualdade, ao contrário de $A$ Decisão, em que os Quatro Agitadores falavam a uma instância suprema, o Coro de Controle. Esta modificação formal vai tornar possível a "A" se mostrar como indivíduo, no sentido psicológico ou mesmo psicanalítico do termo. Se o personagem quer fazer referência a sua ação enquanto membro de um coletivo, enquanto instrumento do Partido Comunista, de imediato passa a utilizar o tratamento "nós".

A - (...) Contra a dúvida quanto à revolução, não havia

Nenhum outro remédio senão a morte do cético.

E eu não tinha olhos para suas mãos

Quando estava diante de meu revólver, de rosto virado para a pedreira

Se elas estavam ou não arruinadas pelo trabalho

Estavam, sim, bem amarradas com cordas

E o matamos com a minha mão

Sabendo que o pão de cada dia da revolução

É a morte de seus inimigos, sabendo que ainda

Temos que arrancar a relva para que o verde fique ${ }^{18}$ ( grifos nossos).

A repetição deste refrão: "Sabendo que o pão de cada dia da revolução [...],

\footnotetext{
16 Apud MAIER- SCHAFFER, 1992, p. 86.

17 Müller, 1987, p. 3-4.

${ }_{18}$ Müller, 1987, p. 9.
} 
sabendo que ainda temos que arrancar a relva para que o verde fique" remete às soluções formais sugeridas pelo compositor Hanns Eisler para $A$ Decisão que, segundo Albrecht Betz, deveria ser uma espécie de anti-oratório, uma inversão de uma Paixão de Bach, principalmente da Paixão segundo São Mateus. "Tudo que tem valor positivo no modelo cristão, isto é, a fé, a compaixão, o sacrifício, etc. mostra-se falso", (perigoso) para o Jovem Camarada e motivo para sua condenação à morte pelo Coro de Controle de A Decisão. Em Mauser, o "pão de cada dia" da oração cristã torna-se o refrão que anuncia na peça esta espécie de anti-Parábola do Julgamento Final, em que o ensinamento, a lição que não deve ser esquecida, consiste em aceitar a condenação à morte de todos os inimigos da revolução, mesmo na hipótese de o inimigo ser ele próprio.

O "Coro" e "A" repetirão esta lição doutrinária oito vezes em três ou quatro páginas do conjunto do texto, justamente nas páginas destinadas ao acontecimento externo, isto é, ao processo judicial. O restante das páginas, em torno de umas dez aproximadamente, tratará de tudo que se passa no interior do indivíduo, referente às dúvidas do ser humano "A".

A - Mas no clamor da batalha, que havia crescido

E crescia ainda mais, estava eu com as mãos ensangüentadas

Eu soldado e baioneta da revolução

E procurava com a minha voz por uma certeza ${ }^{19}$.

A (CORO) - A mim, no entanto, os meus semelhantes conduzem agora ao paredão

E eu que entendo isso não o entendo

Por quê? ${ }^{20}$.

Neste particular, devem ser lembradas as razões pelas quais Müller decidiu-se pela retomada do tema de $A$ Decisão. Mauser é uma peça em que ele se interroga justamente sobre a necessidade da violência a serviço da Revolução. Em suas três peças experimentais - Filocteto, O Horaciano e Mauser - investiga a relação, no interior do marxismo, entre humanismo e terror. Mauser, conforme o próprio Müller o diz, é “a práxis do comunismo que Brecht naturalmente não poderia conhecer em 1920, que ele se recusa a considerar durante sua luta contra o nazismo, mas que ele tem de encarar de frente, em 1953, em seu retorno à RDA".

\section{A peça didática brechtiana, uma forma revista por Müller}

A peça didática é um exercício formal cumprido por um Heiner Müller em busca de uma forma adequada para suas peças. Müller escreve Mauser num momento de crise, em que desconfia da reação passiva demais do seu sonhado "novo público", cuja participação ativa durante a experiência do espetáculo era, naqueles anos, sua preocupação maior. Ele queria que este "novo público" se tornasse seu co-autor, conforme declarou no Prólogo de sua peça $O$ Achatador de Salários, assumindo assim a tarefa de encontrar a solução do "conflito entre o Antigo e o Novo que o escritor é

19 MÜLLER, 1987, p. 14.

${ }^{20}$ MÜLLER, 1987, p. 16-17. 
incapaz de resolver”21. Com Mauser, Heiner Müller colocava à prova, em 1970, a prática brechtiana. Segundo Mayer-Schaffer, esta peça, a última "do ciclo de experiências destaca-se igualmente como a primeira de uma outra trilogia”. Primeira etapa de uma recepção ativa, ela terá prosseguimento numa crítica mais veemente, em 1977, com a peça Hamlet-Máquina, que o levará, em 1979, até $A$ Missão, uma peça que se poderia qualificar como mais tipicamente mülleriana.

Por outro lado, não se deve esquecer que, também em 1977, dois anos antes de $A$ Missão, Heiner Müller encenou o Fragment-Fatzer a partir de fragmentos da peça Declínio do egoísta Johann Fatzer, que Brecht começara a escrever nos anos 1929-1930, mas não chegara a concluir. O Fragment-Fatzer contém elementos de toda a obra de Brecht ou, pelo menos, de toda sua utopia e, para Müller, este trabalho significou a realização de uma montagem que se situa num momento decisivo de sua carreira, em que se encontrava diante da alternativa: "desenvolver uma nova dramaturgia ou renunciar à escritura de peças teatrais. Não consigo enxergar outra saída"22. Müller se sentia num impasse provocado pelo "período de estagnação" que reinava em seu país.

Müller, por esta época, perdera para sempre sua crença em peças com um fim e revelara a importância do interesse do fragmentário:

Existe ainda quem escreva peças com uma conclusão. Estas peças me entediam, talvez menos ao público. [...] Mas nesta hora que estamos vivendo, torna-se necessário utilizar este instrumento para fazer o que lhe interessa, sem levar em conta o que possa estar interessando ao público ${ }^{23}$.

Nesta mesma fonte citada, Müller retoma o tema do eterno retorno, ou seja, de que, para um texto ser eficaz, torna-se necessário que se retrabalhe nele algumas situações-modelo do passado. Segundo o dramaturgo, os Nibelungos são um esboço de Fausto; Os Bandoleiros, de Schiller; de A morte de Danton, de Büchner etc. Por este motivo, a fábula do Fragment-Fatzer, a deserção de quatro homens durante a primeira guerra mundial, que acreditam na iminência da revolução que não virá jamais, será citada por Brecht em $A$ peça didática de Baden-Baden sobre o Acordo. E a morte do Jovem Camarada será o ponto de partida de Mauser.

Se o Jovem Camarada destrói sua máscara e os clássicos (“é tudo uma merda”) e se decide a partir logo para a ação ("pois o homem, o homem vivo, urra e sua miséria rompe todos os diques da doutrina”), "A”, por sua vez, em Mauser, não hesitará também em urrar e revelar suas dúvidas com relação às ordens do Partido. Ele se dirá um homem e recusará a condenação à morte que lhe é imposta. São "atos de loucura" de dois personagens que se identificavam com o Partido e a atitude de "A" ganha peso maior na medida em que é descrito como um seguidor incondicional do Partido que conhece o preço da Revolução.

Esses dois personagens, no entanto, chegarão à mesma conclusão de Fatzer:

\footnotetext{
${ }^{21}$ MÜLLER apud MAYER-SCHAFFER, 1992, p. 83.

22 Apud MAIER-SCHAFFER, 1992, p. 128.

${ }^{23}$ MÜLLER, 1987, p. 7.
} 
Para mim a guerra acabou,

volto correndo para casa.

Estou cagando para a ordem do mundo.

Estou perdido.

Curiosamente, a situação é a mesma da peça $A$ verdadeira história de $A b Q$, de Christoph Hein, outro autor contemporâneo alemão, em que Wang e AhQ, dois prisioneiros, estão também esperando por uma revolução iminente que virá, mas que, ironicamente, não os convidará para integrar o novo governo revolucionário.

Fatzer, como o Jovem Camarada, será assassinado por seus companheiros por se tratar de um homem que tem visões, de alguém que luta contra o quotidiano. "Um ser ativo", segundo Dimiter Gotscheff, o diretor búlgaro que, em 1993, montou Fatzer no Schauspiel de Colônia, em quem ele vê uma representação do grande

[...] dilema tragicômico do socialismo. Tudo começou com Maïakovski [Não esqueçamos que Brecht escreve $A$ Decisão em homenagem a Maïakovski] e Babel para atingir, em seguida, engenheiros, médicos, militares. Os indivíduos mais fortes foram massacrados, pois a sociedade não podia suportar que alguém pudesse formular as coisas de forma diferente, pudesse entrever outras soluções, etc. ${ }^{24}$.

Em contrapartida, se Fatzer e o Jovem Camarada são liquidados por suas reações espontâneas, por erros sucessivos atribuídos à sua juventude e inexperiência, que colocarão em perigo outras pessoas, "A" e o personagem de $A$ Missão serão escolhidos, justamente, por deterem uma grande experiência.

\section{CORO}

Você ["A"] lutou na frente da guerra civil

$\mathrm{O}$ inimigo não encontrou fraqueza alguma em você.

Nós não havíamos encontrado fraqueza alguma em você² .

A partir de um texto de janeiro de 1977, Adeus à peça didática, Müller se diz a favor do "derrotismo construtivo" e nega a eficácia da lição. Para ele, o apocalipse de $A$ Decisão teria "caducado, a história devolveu o processo para a rua, mesmo os coros sabidos de cor não cantam mais, o humanismo quando se manifesta é através do terrorismo, o coquetel Molotov é o último acontecimento educativo burguês"26.

Mas, em 1988, Müller retorna curiosamente à peça didática. Escreve $A$ Estrada de Wolokolamsk (em francês, traduzida como La Route des chars [A Estrada dos Tanques]), em que um personagem, o Comandante, obrigado a matar um "traidor", concretiza seu desejo de libertar o condenado num sonho que ele tem, e que consi-

${ }^{24}$ GOTSCHEFF, 1993, p. 28.

25 MÜLLER, 1987, p. 3.

26 MÜLLER, Heiner. Hamlet-machine, Horace-Mauser-Héraclès 5 et autres pièces. Traduits de l'allemand par Jean Jourdeuil et Heinz Schwarzinger. Paris: Les Éditions de Minuit, 1985. p. 68. 
dera um "movimento espontâneo de seu outro eu”.

Em seu uniforme meu outro eu

Queria pedir perdão ao morto,

Desta morte que tinha sido meu trabalho ${ }^{27}$.

\section{Conclusão: para que serve uma peça didática?}

Para Brecht, peças didáticas são aquelas a serem interpretadas

[...] de forma idêntica a alunos numa escola, através de uma elocução voluntariamente marcada, revendo sem cessar as passagens difíceis, para descobrir seus significados ou fixá-los na memória. Não são peças para serem "vistas" pelo público habitual dos teatros - o público burguês - mas autênticos exercícios dramáticos destinados às crianças das escolas, aos membros de grupos de jovens, de grupos leigos, de associações proletárias e principalmente aos corais de trabalhadores.

É para instruir os participantes dessas coletividades que ele propõe suas peças didáticas, "na esperança de que eles possam ser socialmente influenciados pela execução de modos bem precisos de ação" 28 .

Segundo Bernard Dort, em seu ensaio Exercícios didáticos, Bertolt Brecht estava radiante com estes corais operários que chegaram a ter, na Alemanha, meio milhão de participantes, e insistia em que se deveria chamar a atenção para a "forma de atingir o resultado, para sua execução, e não para o resultado deste novo trabalho teatral"29. Tornava-se necessário oferecer a esses corais um novo repertório.

No que se refere à Decisão, por exemplo, Brecht dizia que esta peça nunca deveria ser representada, pois, insistia, "só o intérprete do Jovem Camarada pode aprender com ela alguma coisa e, mesmo assim, se tiver representado também um dos agitadores e tiver cantado no Coro de Controle" 30 .

Quando, em nossos dias, autores contemporâneos do teatro alemão continuam a utilizar este tipo de teatro épico por excelência, centrado na interrupção constante da ação dramática por intérpretes que se perguntam sobre o significado de certas passagens de um texto ou de uma canção, podemos pensar na grande atualidade desta forma didática, longe de estar definitivamente esgotada.

Para Müller, a peça didática é um trabalho entre outros, "organizado pelo coletivo e organizando o coletivo”, cuja representação diante de um público só é possível na medida em que esse público tem a possibilidade de controlar o jogo com respeito ao texto e o texto com respeito ao jogo.

Voltamos, então, a esta preocupação constante do teatro mülleriano, de um teatro em que o público possa chegar a uma participação ativa, de um espetáculo em que o público torna-se ator e em que todos atuam juntos.

\footnotetext{
27 Apud MAYER-SCHAFFER, 1992, p. 115.

${ }_{28}$ BRECHT, Bertolt. Sur la pièce didactique. In: 1972. p. 341.

29 DORT, Bernard. Des exercices didactiques. In: et forme épique. Paris: Seuil, 1960. p.76.

${ }_{30}$ DORT, 1960, p. 351. Écrits sur le théâtre I. Paris: L’Arche, . Lectures de Brecht, suivi de pédagogie
} 
Chegar-se-ia, assim, a uma repartição do texto proposta a partir de um esquema variável.

A exemplo de Brecht, Müller sugeriu uma multiplicidade de variantes possíveis na distribuição de papéis: 1) o coro põe à disposição do protagonista um intérprete do protagonista (A1);2) Todos os membros do coro, sucessiva ou simultaneamente, atuam como protagonista; 3 ) o protagonista fica encarregado de algumas partes corais, enquanto A1 o representa.

O jogo, consistindo, principalmente, em tornar possível a todos os membros do grupo uma transmissão coletiva das várias experiências.

Para transformar uma sociedade, é preciso compreendê-la em sua unicidade e, ao mesmo tempo, em seu movimento, o que permitirá "analisar esta sociedade [...] como o produto instável de situações individuais e de condições objetivas" ${ }^{31}$.

A comparação entre os dois textos revelou-nos um fenômeno que nos interessa particularmente: a conexão vital entre um texto que cita e um texto que se descobre citado. O prazer de descobrir em Müller o eco longínquo de idéias sugeridas originariamente por Brecht, a emoção de descobrir no discípulo a possibilidade de fazer reviver, em textos novos, uma intenção oculta, não explícita do texto anterior.

$\mathrm{Da}$ ascese religiosa do Jovem Camarada às dúvidas de "A", em suas dificuldades individuais para estar de acordo, podemos ouvir, enquanto leitores, um grito de vida que passa de um indivíduo ao outro. E foi este grito de vida que nos contaminou a todos, professor e alunos (atores e espectadores), nas apresentações de nossas leituras das duas peças didáticas alemãs.

${ }^{31}$ DORT, 1960, p. 91. 


\section{REFERÊNCIAS}

BAUDELAIRE, Charles. O convite à viagem. In: Pequenos poemas em prosa. Tradução de Aurélio Buarque de Hollanda. Rio de Janeiro: J. Olympio, 1950. (Coleção Rubáiyat).

BETZ, Albrecht et al. L'état d'urgence chez Carl Schmitt et La décision chez Bertolt Brecht. In: STORCH, Wolfgang (Dir.). Brecht après la chute. Confessions, mémoires, analyses. Paris: L'Arche, 1993.

BRECHT, Bertolt. A decisão (1929-1930). In: . Teatro completo. Tradução de Ingrid

Dormien Koudela. Rio de Janeiro: Paz e Terra, 1988. v. 3.

BRECHT, Bertolt. Pequeno organon para o teatro (fragmento 75). In: Estudos sobre teatro. Tradução de Fiama Pais Brandão. Rio de Janeiro: Nova Fronteira, 1978.

BRECHT, Bertolt. Sur la pièce didactique. In: .Écrits sur le théâtre I. Paris: L’Arche, 1972.

CAILLOIS, Roger. Les jeux et les hommes. Paris: Gallimard, 1967.

DORT, Bernard. Des exercices didactiques. In: Lectures de Brecht, suivi de pédagogie et forme épique. Paris: Seuil, 1960.

GOETHE. Les années d'apprentissage de Wilhelm Meister. Traduit de l'allemand par Jeanne Ancelet-Hustache. Paris: Aubier-Montaigne, 1983.

GOTSCHEFF, Dimiter. Nous maintiendrons le virus en vie. In: Brectht après la chute: confessions, mémoires, analyses. Paris: L'Arche, 1993.

HECHT, Werner. Devant la commission d'enquête sur les activités antiaméricaines. Entretiens avec Brecht. Traduit de l'allemand par François Mathieu. Paris: Éditions Messidor, 1988.

HENRIOT, Jacques. Le jeu. Paris: Synonyme, 1983.

JANKÉLÉVITCH, Vladimir. L'aventure, l'ennui, le sérieux. Paris: Aubier-Montaigne, 1963.

MAIER-SCHAFFER, F. Heiner Müller et la Lebrstück. Berne: P. Lang, 1992.

MÜLLER, Heiner. Hamlet-machine, Horace-Mauser-Héraclès 5 et autres pièces. Traduits de l'allemand par Jean Jourdeuil et Heinz Schwarzinger. Paris: Les Éditions de Minuit, 1985.

MÜLLER, Heiner. Quatro textos para teatro: Mauser, Hamlet-máquina, a missão, quarteto. Apresentação de Fernando Peixoto. São Paulo: Editora Hucitec: Associação Cultural Bertolt Brecht, 1987. 